\title{
THE IMPACT OF SCHOLARSHIP STATUS ON THE EXPERIENCES OF INTERNATIONAL GRADUATE STUDENTS IN THE U.S.
}

\author{
RESEARCH ARTICLE
}

\section{Cebrail KARAYiĞì'1}

1 Assistant Professor, Pittsburg State University, Psychology \& Counseling, ckarayigit@pittstate.edu, ORCID: 0000-0002-9920-9642.

\begin{abstract}
:
Each year, different countries around the world spend millions of dollars to sponsor thousands of international students to enroll in graduate programs in the United States. However, little is known as to whether, how, and under what conditions their scholarship status may influence their overall experiences. Drawing on a survey completed by international graduate students ( $=107)$, the effect of government-sponsored scholarship programs on international graduate students' overall experiences is discussed. The findings of this study revealed that government-sponsored scholarship students were less competent in their level of perceived English proficiency and face more challenges in their studies compared to non-scholarship students. This study informs both practitioners in international student services offices of U.S. universities and Turkey's Ministry of National Education scholarship program to be better equipped with the knowledge of whether/how scholarship status can impact international graduate students' overall experiences.
\end{abstract}

Anahtar Kelimeler: Turkish international graduate students, English proficiency, scholarship status 


\title{
BURS DURUMUNUN AMERIKA BIRLEŞIK DEVLETLERI'NDEKI ULUSLARARASI LISANSÜSTÜ ÖĞRENCILERIN DENEYIMLERINE ETKISI
}

\begin{abstract}
Öz: Her yıl, dünyanın farklı ülkeleri binlerce uluslararası öğrencinin Amerika Birleşik Devletleri'ndeki lisansüstü programlara kaydolmasına sponsor olmak için milyonlarca dolar harcıyor. Bununla birlikte, burs durumlarının genel deneyimlerini etkileyip etkileyemeyeceği, nasıl ve hangi koşullarda etkileyebileceği konusunda çok az şey bilinmektedir. Uluslararası lisansüstü öğrenciler tarafından tamamlanan bir anketten ( $\mathrm{N}=107)$ yola çıkararak, devlet destekli burs programlarının uluslararası lisansüstü öğrencilerin genel deneyimleri üzerindeki etkisi tartışılmaktadır. Bu çalışmanın bulguları, devlet destekli burslu öğrencilerin algılanan İngilizce yeterlilik düzeylerinde daha az yetkin olduklarını ve burslu olmayan öğrencilere kıyasla çalışmalarında daha fazla zorlukla karşılaştıklarını ortaya koydu. Bu çalışma, hem ABD üniversitelerinin uluslararası öğrenci hizmetleri ofislerindeki uygulayıcıları hem de Türkiye Milli Eğitim Bakanlığı burs programını, burs durumunun uluslararası lisansüstü öğrencilerin genel deneyimlerini etkileyip etkileyemeyeceği/nasıl etkileyebileceği konusunda daha iyi donanımlı olmaları konusunda bilgilendirmektedir.
\end{abstract}

Anahtar Kelimeler: Türk uluslararası lisansüstü öğrencileri, İngilizce yeterlik, burs durumu

\section{Introduction}

A report by the Institute of International Education (2015) found that 74\% of prospective international students worldwide reported the U.S. as their top choice of country in which to pursue their studies. The majority of these students showed a more positive view of studying in the U.S. than in other countries because of several reasons such as opportunities in many different fields that are oftentimes not afforded in their home countries, a wide range of schools and programs, and high quality higher education system (IIE, 2015; IIE, 2019). Although the pandemic has contributed to a decrease in international student enrollment at American colleges and universities recently (Dennis, 2020), the number of international in the United States set an all-time high in the 2018-2019 academic year (Institute of International Education, 2019). Given the increasing participation and attainment of international students in higher education in the U.S., the unique nature of the experiences and challenges of international students in graduate programs in the U.S. are particularly worthy of investigation and better understanding. 
Despite the numerous challenges associated with leaving the home country and cross-cultural transitions (Lee, 2013), many international graduate students enroll in graduate programs in the United States each year (Council of Graduate Schools, 2018). International graduate students' experiences have been studied extensively (Click, 2018; Burkholder, 2014; Ku, Lahman, Yeh \& Cheng, 2008; Kuo, 2011; Lee, 2013; Zhai, 2002), but the literature on how their scholarship status can impact their experiences is limited. It is important to highlight that scholarship students make up a sizable portion of the international graduate student body in the United States. These sponsored students are frequently those students who receive a scholarship from their home government. Interestingly, the level of motivation to adapt to American culture can be low among these students because of the intention of returning to their home country (Sumer, 2009). This study examines whether scholarship students and non-scholarship students differ in their levels of perceived English proficiency and perceived challenges faced.

It is important to understand that being a government-sponsored scholarship student can be a very stressful experience because of the requirement and context of the scholarship program (Arbona, Bullington \& Pisecco, 2001; Karayigit \& Joseph, 2020). For example, while the required period to complete a doctoral degree is four years, some doctoral programs require a significantly longer degree process. Many doctoral students have failed to complete their program within four years due to having significantly more demands placed on them than ever before. Therefore, being an international graduate student in the U.S. might be highly challenging and complex due to government-sponsored scholarship programs' requirements.

As a subgroup of the international student population, Turkish international graduate students are typically not an exception in the concept of facing unique challenges (Gertzog, 2011; Karayigit \& Joseph, 2020; Tatar, 2005; Turan, 2012). In her study with Turkish graduate students in social sciences, Turan (2012) found that the language barrier is one of the major issues Turkish graduate students face in their studies. Similarly, another study examined the experience of six Turkish international graduate students at a Midwestern U.S. university and found that the language barrier is one of the most common issues the participants face in the U.S. (Burkholder, 2014). In this study, some participants reported that their class preparation is five times more than a native speaker's class preparation time because of language challenges.

Previous studies also focused on Turkish international scholarship students' decision to home country after completing their studies (Güngör \& Tansel, 2008; Karayigit \& Joseph, 2020; Kurtuluş, 1999; Tansel \& Güngör, 2003; Tuzcu, 2003). For example, in a recent study, more than half of Turkish graduate students indicated they intended to return to their home countries upon graduation (Karayigit \& Joseph, 2020). While Turkey's Ministry of Education has sponsored many students to pursue graduate studies in U.S. universities (see Celik, 2012), students have to come back to fulfill an obligatory 
The Impact of Scholarship Status on the Experiences of International Graduate Students in the...

service equal to twice they have spent abroad. In order to avoid losing their scholarship status and paying compensation to their government, government-sponsored scholarship students are also required to complete their master's or doctoral degree in a restricted period. Previous studies show that Turkish scholarship students studying in the U.S. are found to experience more adjustment problems because of the pressure to be successful and not to lose their scholarship (Arbona, Bullington \& Pisecco, 2001). Therefore, a better understanding of the impact of scholarship status on international graduate students' perceived English proficiency and the level of perceived challenges is also warranted.

To these ends, the present study addresses the following two research questions: (a) among international graduate students, are there differences between scholarship and non-scholarship students in their levels of perceived English proficiency and perceived challenges faced? And (b) among Turkish international graduate students, are there differences between scholarship and non-scholarship students in their levels of perceived English proficiency and perceived challenges faced?

\section{Method}

This study employs a descriptive research method intended to examine differences between scholarship and non-scholarship students. The population for this study was international graduate students currently enrolled in U.S. universities. Data were collected via online surveys with graduate students who were enrolled in masters and doctoral level programs at universities in the U.S. Potential participants were contacted by forwarding the survey link through selected online listserv (e.g., CESNET) and sent an email to the personal list of contacts who meet the study criteria. This latter approach also involved convenient sampling, through including participants who are easy to reach. Demographic information such as gender, country of origin, their perception of their English proficiency level, their perceptions of the challenges they face in their studies, and scholarship status was requested.

\section{Sample}

To address the research questions that pertain to different subgroups of types of international graduate students, the researcher aimed to have participants from two broad groups: scholarship students and non-scholarship students. Within the group of international graduate students, subsamples of Turkish and non-Turkish students, as well as scholarship and non-scholarship students, were obtained. The present study included a sample of $\mathrm{N}=107$ international graduate students enrolled in higher educational institutions from across the United States. The sample was $63 \%$ male, with $50 \%$ identified as a government-sponsored scholarship student. Participants anonymously completed an online survey comprising a demographic questionnaire, including the question "Are you sponsored by your home government?" (with response options of "Yes, I am a scholarship student by my government" and "No, I am not a scholarship 
student by my government"). As shown in Table 1, 53 participants were sponsored by their home government, and 54 students were not sponsored by their home government. Participants were also asked to rate their perception of their level of English proficiency and the challenges they face in their studies on a scale of 1 to 5 . While 1 represented very low proficiency and very little challenge (respectively), 5 represented very high proficiency and too much challenge (respectively).

Table 1. Demographic data of the population

\begin{tabular}{|c|c|c|}
\hline Value & Frequency & Percent \\
\hline \multicolumn{3}{|c|}{ Participants by Scholarship Status } \\
\hline Scholarship & 53 & 49.5 \\
\hline Non-Scholarship & 54 & 50.5 \\
\hline \multicolumn{3}{|l|}{ Participants by Gender ${ }^{*}$} \\
\hline Male & 67 & 63.2 \\
\hline Female & 39 & 36.8 \\
\hline \multicolumn{3}{|c|}{ Turkish International Graduate Students } \\
\hline Scholarship & 38 & 59.4 \\
\hline Non-Scholarship & 26 & 40.6 \\
\hline Total & 107 & 100.0 \\
\hline
\end{tabular}

*One participant did not identify his/her gender

For this research, permission was obtained from the Institutional Review Board of the ethics committee of Duquesne University, Pittsburgh, PA, under the rules for expedited review (Protocol \#2016/02/13).

\section{Data Analysis}

The results were analyzed with SPSS (version 24). Frequencies and t-tests were utilized. Specifically, a series of independent sample t-tests were conducted to examine research questions one and two. First, an independent t-test was conducted to assess if the level of English proficiency and challenges faced differ between scholarship and non-scholarship international graduate students. Another independent t-test was used to determine whether there was a significant difference in English proficiency and challenges faced between Turkish scholarship students and non-scholarship students.

\section{Results}

Participants were asked to rate their perception of their English proficiency and their perception of challenges faced in their graduate studies (using a scale from $1=$ not at all proficient to $5=$ extremely proficient). Independent sample $t$-tests were conducted to examine differences in levels of English proficiency and challenges faced as a func- 
The Impact of Scholarship Status on the Experiences of International Graduate Students in the...

tion of current scholarship status (sponsored by the home government or not) among international graduate students. Scholarship graduate students $(M=3.57, S D=0.66)$ were significantly lower in their mean level of perceived English proficiency than non-scholarship graduate students $(M=4.04, S D=0.77), t(105)=-3.367, p=0.00$. On the other hand, the difference between scholarship international graduate students and non-scholarship international graduates appeared to be marginally significant in their levels of perceived challenges faced $(t(104)=1.897, p=0.06)$. Further, the effect size for the level of perceived English proficiency and level of perceived challenges faced were at $d=.66$ and $d=.37$, which are considered a medium effect size using Cohen's (1988) criteria. Overall, findings revealed non-scholarship international students had a higher level of perceived English proficiency and a lower level of challenges than scholarship students.

Table 2. T-Test

\begin{tabular}{|c|c|c|c|c|c|c|c|c|}
\hline \multicolumn{9}{|c|}{ Scholarship } \\
\hline & Status & $N$ & $M$ & $S D$ & SEM & $t$ & $d f$ & $p$ \\
\hline \multirow[t]{2}{*}{ English Proficiency } & Yes & 53 & 3.57 & 0.665 & 0.091 & -3.367 & 105 & 0.00 \\
\hline & No & 54 & 4.04 & 0.776 & 0.106 & & & \\
\hline \multirow[t]{2}{*}{ Challenges Faced } & Yes & 53 & 3.34 & 0.758 & 0.104 & 1.897 & 104 & 0.06 \\
\hline & No & 53 & 3.04 & 0.876 & 0.120 & & & \\
\hline
\end{tabular}

Finally, to examine research question two, independent sample $t$-tests were conducted to examine differences in levels of English proficiency and challenges faced as a function of current scholarship status (sponsored by the home government or not) among Turkish international graduate students. Turkish scholarship graduate students $(M=3.58, S D=0.68)$ were significantly lower in their mean level of perceived English proficiency than Turkish non-scholarship graduate students $(M=4.00, S D=$ $0.75), t(62)=-2.330, p=0.02$. On the other hand, the difference between Turkish scholarship international graduate students and Turkish non-scholarship international graduates appeared to be marginally significant in their levels of perceived challenges faced $(t(62)=1.742, p=0.08)$. Further, the effect size for the level of perceived English proficiency and level of perceived challenges faced were at $d=.59$ and $d=.43$, which are considered a medium effect size using Cohen's (1988) criteria. 
Table 3. T-Test

\begin{tabular}{llccccccc}
\hline & Turkish Students & $N$ & $M$ & SD & SEM & $t$ & $d f$ & $p$ \\
\hline \multirow{2}{*}{ English Proficiency } & Scholarship & 38 & 3.58 & 0.683 & 0.111 & -2.330 & 62 & 0.02 \\
& Non-Scholarship & 26 & 4.00 & 0.748 & 0.147 & & & \\
Challenges Faced & Scholarship & 38 & 3.39 & 0.755 & 0.122 & 1.742 & 62 & 0.08 \\
& Non-Scholarship & 26 & 3.04 & 0.871 & 0.171 & & & \\
\hline
\end{tabular}

\section{Discussion, Conclusion, and Future Directions}

This article was one of the few studies that examine the differences between scholarship and non-scholarship international graduate students in their levels of English proficiency and challenges faced. Scholarship international graduate students are usually expected to face fewer challenges (e.g., reducing financial burden) and finding more energy and time to enhance their learning and focus on their studies. However, the notion that scholarship international graduate students were expected to have a higher level of English proficiency and lower level of challenges faced compared to non-scholarship international graduate students was not supported. Although scholarships can provide great benefits (e.g., reducing the financial burden, finding more energy/time to focus on studies rather than working part-time), these benefits are only one piece of a bigger puzzle that shapes the experiences of scholarship students.

The major findings of this study are that scholarship students were less competent in their level of perceived English proficiency than non-scholarship students, and scholarship students had a higher mean level of challenges compared to non-scholarship students. This finding is consistent with Sumer's (2009) study that has shown that students who intend to return home country after graduation may have a lower level of motivation to adapt to American culture, which might affect their level of perceived challenges and perceived English proficiency. In other words, since international students' motivation is significantly associated with their sociocultural adaptation (Sumer, 2009; Hsu, 2011), scholarship students have more tendency to go into survival mode (e.g., not to lose the scholarship, avoid failure), which possibly influence the quality of their overall experiences (e.g., English proficiency, challenges faced). These findings also support the assertion by Celik's (2014) study that the effectiveness of government-sponsored scholarship programs is questionable. Unfortunately, scholarship status does not seem to be promoting better outcomes because of fear of failure (e.g., lose scholarship status). However, scholarship programs should encourage students to challenge themselves to broaden their potential in their studies. This article suggests that government-sponsored scholarship programs need to be well-structured to encourage students to move from simply surviving to thrive in their studies actively. 
The Impact of Scholarship Status on the Experiences of International Graduate Students in the...

The current findings suggest the possibility that government-sponsored scholarship students have some unique challenges and needs that are not oftentimes faced by non-scholarship international graduate students. The finding of this study is consistent with Poyrazli, Arbona, Bullington \& Pisecco's (2001) study highlighting that scholarship students typically have stressful experiences because of the pressure to keep their scholarship status. This pressure may lead them to focus on surviving instead of thriving in their studies. More specifically, scholarship international graduate students are typically required to fulfill specific obligations (e.g., completing their education in a restricted period, paying compensation to their government in the event of failure), whereas non-scholarship students graduate students typically do not have such requirements. The quality of experiences for students who have a requirement to complete their degree in a restricted period or under stress for fear of failure might be different from students who do not have such a requirement. Such requirements could have a negative impact on their overall experiences and lead to more stressful experiences. Overall, their motivation and experiences could be negatively affected when they study out of fear of failure (Elliot \& Murayama, 2008).

While this article outlines the role and impact of scholarship status on international graduate students' experiences, an in-depth analysis of the scholarship program's effectiveness is necessary to provide a greater understanding of specific issues that are of particular concern to international graduate scholarship students' experiences. Turkey's Ministry of National Education study-abroad program can take further steps to ensure scholarship students are fully prepared for the rigor and demands of their studies and equipped with all the skills needed for their success and social integration in the new culture. While the most exceptional scholars are accepted to the study-abroad program (Celik, 2012), this program should consider having more rigorous language proficiency standards in accepting students into this program. However, the challenges scholarship students face should not be looked at solely in terms of English proficiency. Other factors such as signing an official contract pledging that they would return to Turkey after their education (Celik, 2012), being undecided about returning to one's home country (Karayigit \& Joseph, 2020), fear of finding themselves in an unproductive environment after returning country (Tansel \& Gungor, 2002) should also be considered when evaluating the effectiveness of the study-abroad program. Overall, this study's findings call for effective intervention programs, policies, and practices focused on intentionally preparing scholarship students for a smooth transition and successful educational experiences abroad.

The self-report nature of instruments was a major limitation because of possible response bias. For example, international graduate students were asked to rate their level of English proficiency and the perception of challenges faced in their studies. In this case, some participants may have altered their responses to appear more favorable. According to Antin and Shaw (2012), survey self-reports can indicate a potential 


\section{MİLLî EĞİTiM • Cilt: 50 • Özel Sayı/2021 • Sayı: 1, (1121-1130)}

presence of social desirability bias. Therefore, response bias, a threat to internal validity, could have been an issue for this study. Another potential limitation of this study is the researcher, a scholarship international graduate student in the U.S. Although the researcher made every attempt to maintain objectivity and not bring his own attitudes and values into the study, there may nonetheless have been inadvertent researcher bias. Also, it is possible that the knowledge of some of the participants that the researcher shared the characteristic of being an international student himself may have biased how they reported their data. This is because some participants may feel they want to respond to the survey to fulfill their role for the study's success. One recommendation for future researchers would be to employ qualitative research designs to examine in more depth and, in their own words, graduate students' overall experiences. For example, interview methods and open-ended questionnaires can allow respondents to provide more details in their responses.

\section{References}

Antin, J., \& Shaw, A. (2012, May). Social desirability bias and self-reports of motivation: A study of Amazon Mechanical Turk in the US and India. In Proceedings of the SIGCHI Conference on Human Factors in Computing Systems (pp. 2925-2934). Austin, TX: ACM. https://doi. org $/ 10.1145 / 2207676.2208699$

Burkholder, J. R. (2014). Reflections of Turkish international graduate students: Studies on life at a US midwestern university. International Journal for the Advancement of Counselling, 36(1), 43-57. https://doi.org/10.1007/s10447-013-9189-5

Celik, S. (2012). Turkey's Ministry of National Education study-abroad program: Is the MoNE making the most of its investment? The Qualitative Report, 17(20), 1-31. http:/ / www.nova. edu/ssss/QR/QR17/celik.pdf

Cohen, J. (1988). Statistical power analysis for the behavioral sciences (2nd ed.). Hillsdale, NJ: Lawrence Earlbaum Associates.

Click, A.B. (2018). International graduate students in the United States: Research processes and challenges. Library \& Information Science Research, 40(2), 153-162. https://doi.or$\mathrm{g} / 10.1016 / \mathrm{J}$. LISR.2018.05.004

Dennis M. J. (2020). COVID-19 will accelerate the decline in international student enrollment. Recruiting \& Retaining Adult Learners, 22(12), 1-7. https:/ / doi.org/10.1002/nsr.30639

Elliot, A. J., \& Murayama, K. (2008). On the measurement of achievement goals: Critique, illustration, and application. Journal of Educational Psychology, 100(3), 613-628. https://doi. org $/ 10.1037 / 0022-0663.100 .3 .613$

Gertzog, R. (2011). Non-linguistic challenges for Turkish students in American higher education (Master Thesis). https://eric.ed.gov/?id=ED525728

Güngör,N.D.,\&Tansel,A.(2008). Brain drain from Turkey:The caseof professionals abroad. International Journal of Manpower, 29(4), 323-347. https://doi.org/10.1108/01437720810884746 
The Impact of Scholarship Status on the Experiences of International Graduate Students in the...

Hsu, C. H. (2011). Factors influencing international students' academic and sociocultural transition in an increasingly globalized society (Doctoral Dissertation). Available from ProQuest Dissertations and Theses database. (UMI No. 3455443)

Institute of International Education. (2019). "International Student Enrollment Trends, 1948/492018/19." Open Doors Report on International Education Exchange. Retrieved from https://www.iie.org/opendoors

Karayigit, C., \& Joseph, M. (2020). The role of motivational orientations and returning home country: Turkish international graduate students in the U.S. Hacettepe University Journal of Education. Advance online publication. https:/ / doi.org/10.16986/HUJE.2020063850

Ku, H. Y., Lahman, M. K., Yeh, H. T., \& Cheng, Y. C. (2008). Into the academy: Preparing and mentoring international doctoral students. Educational Technology Research and Development, 56(3), 365-377.

Kurtuluş, B. (1999). Amerika birleşik devletleri'ne Türk beyin göçü [Turkish brain drain to the United States]. İstanbul: Alfa Yayınları.

Kuo, Y. H. (2011). Language challenges faced by international graduate students in the United States. Journal of International Students, 1(2), 38-42. https:/ / doi.org/10.32674/jis.v1i2.551

Lee, K. C. G. (2013). Training and educating international students in Professional psychology: What graduate programs should know? Training and Education in Professional Psychology, 7(1), 61-69. https://doi.org/10.1037/a0031186

Okahana, H., \& Zhou, E. (2018). International graduate applications and enrollment: Fall 2017. Washington, DC: Council of Graduate Schools. https://cgsnet.org/ckfinder/userfiles/ files/Intl_Survey_Report_Fall2017.pdf

Poyrazli, S., Arbona, C., Bullington, R., \& Pisecco, S. (2001). Adjustment issues of Turkish college students in the United States. College Student Journal, 35(1), 52-62.

Sumer, S. (2009). International students' psychological and sociocultural adaptation in the United States (Doctoral Dissertation). http://scholarworks.gsu.edu/cps_diss/34

Tansel,A., \& Güngör, N. D. (2003). 'Brain drain' from Turkey:Survey evidence of student non-return. Career Development International, 8(2), 52-69. https://doi.org/10.1108/13620430310465453

Tatar, S. (2005). Classroom participation by international students: The case of Turkish graduate students. Journal of Studies in International Education, 9(4), 337-355. https://doi. org $/ 10.1177 / 1028315305280967$

Turan, E. (2012). Language Anxiety Among Turkish Graduate Students in Social Sciences in the US (Master Thesis). https://uh-ir.tdl.org/bitstream/handle/10657/671/TURAN-THESIS-2012.pdf? sequence $=1 \&$ isAllowed $=y$

Tuzcu, G. (2003). Lisansüstü öğretim için yurtdışına öğrenci göndermenin planlanması [Planning of sending students abroad for graduate studies]. Millî Ĕ̆itim Dergisi, 16(3), 324-340. http://dhgm.meb.gov.tr/yayimlar/dergiler/Milli_Egitim_Dergisi/160/tuzcu.htm

Zhai, L. (2002). Studying International Students: Adjustment Issues and Social Support. San Diego, CA: Office of Institutional Research, San Diego Community College District, 1-20. 